\title{
Learning to belong? 'Culture' and 'Place Making' among children and young people in Hull, UK City of Culture 2017
}

Josef Ploner and Lisa Jones, School of Education, Faculty of Arts, Cultures and Education, University of Hull

\begin{abstract}
Despite the rise of 'child-friendly cities' internationally, and a growing interest in youth engagement in urban planning, the role of children and young people in culture-led regeneration and 'place making' schemes, remains under-researched. Notwithstanding the wealth of research into childhood and youth cultures, little is known about the ways in which the abstract (and perhaps predominantly 'adult') notions of 'culture' and 'place' are negotiated by younger citizens. Drawing on participative research with schools across Hull, the UK City of Culture 2017, this contribution explores children's and young people's understandings of culture and place within this cultural regeneration event. Although our findings suggest that the City of Culture designation has brought benefits to children and young people in a marginalised city, there is still much to be learned from their often personal and informal interpretations of 'place' and 'culture', as well as the role played by schools in this context.
\end{abstract}

Keywords: culture-led regeneration, Hull 2017, UK City of Culture, children, young people, education;

\section{Introduction}

Whilst children and youth participation in urban development and planning has received increased scholarly attention over recent years (Christensen et al. 2017; Elshater 2018), surprisingly little is known about the role children and young people play within culture-led urban regeneration.

Perhaps this lack of knowledge owes much to the fact that, in the context of regenerative urban planning, the notion 'culture' itself continues to be widely associated with traditionally 'grown-up' conceptions of art, creative expression, or the intellectual achievements of 'high culture', which seem to lie at odds with the seemingly more 'natural' developmental stages of childhood and youth (Taylor 2011). Underpinned by a utilitarian logic of socio-economic growth, the 'culture' in cultureled urban regeneration seems to remain largely confined to 'adult' spheres of planning, policy making and investment; particular 'adult' spaces (i.e. cultural quarters or precincts; heritage zones); as well as specific social strata of a particular age (i.e. educated middle classes, 'young' professionals). This is not to argue that children and young people are entirely excluded from urban cultural participation. In fact, regenerative culture-led programmes tend to emphasise the positive long-term impact they have on younger generations, who are seen as the future beneficiaries of job creation, place image, and more far-reaching socio-economic change (Boland et al. 2017). Likewise, the continuing growth of an international 'child-friendly cities' movement (Elshater 2018), as well as increased interest in cultural offers tailored around the 'needs' of children (Colbert 2011), indicate that urban cultural planning is changing in favour of young citizens. 
Despite these positive changes, and a long-standing interest in the creative potentials of urban childhood and youth cultures (Dillabough \& Kennelly 2010; Woodman \& Bennett 2015), little is still known what 'culture' means to children and young people, particularly in the context of culture-led urban regeneration. This is pertinent in large-scale programmes such as 'European Capital of Culture' (ECOC), or its smaller UK counterpart 'City of Culture' (UKCoC), where 'culture' becomes a powerful discursive currency that permeates everyday negotiations of place identity, community, and change among a wide range of stakeholders.

In this article we ask what children and young people perceive to be 'culture' in the context of culture-led urban regeneration, how they negotiate this contested concept, and how their understanding of 'culture' may affect their sense of place. The findings we present emerge from qualitative research with children, young people and educators in Hull, a city in the North of England, which was designated 'UK City of Culture' (UKCoC) in 2017. This temporal, yet investmentintense, event sought to elevate the Yorkshire port city from socio-economic decline, and to lastingly improve its national and international image (Hull 2017 Ltd, 2016). Hull's status as UKCoC offered abundant opportunities to investigate children's and young peoples' perceptions of culture, since organisers identified them as key stakeholders in the overall programme (Hull 2017 Ltd, 2016). A variety of cultural events were specifically designed for children, and a 'Learning and Participation' team was formed to implement an ambitious educational programme at schools across the city. For the sake of clarity, and being aware of the contested definitions surrounding 'childhood' and 'youth' in academic and public discourses, in this article we employ the term 'children' for 8-9 yearsold primary school pupils, and the term 'young people' for 14-15 years-old secondary school pupils, who represent the main research sample in this study.

\section{Place making among children and young people in culture-led urban regeneration}

Despite significant advances in research about (and with) children and young people in cultural geography, urban and education studies, their role in culture-led urban regeneration has received limited scholarly attention. In UK urban planning and policy making, the participation of children and young people in the cultural industries, arts, and heritage has been harnessed as a catalyst for communal wellbeing, educational attainment, innovation and employment, and a pathway towards sustainable urbanism (Christensen et al. 2017; Warwick Commission 2015; ACE 2014). However, scholars emphasise many barriers to youth participation which arise from conflicting ideas and values associated with 'culture' (i.e. public-private, high-popular), which can lead to apathy, voluntary disengagement, affective displacement, or cultural resistance (Parkinson et al. 2014; Butcher \& Dickens 2016). Perhaps most notably, such tensions manifest themselves in socioeconomically disadvantaged post-industrial urban communities, which are repeatedly, yet often 
mistakenly, associated with a lack of cultural capital which distances them from normative middleclass ideas of culture (Bennett et al. 2009; Jancovich \& Hansen 2018). In a similar vein, and despite the recognised potential of cultural diversity in post-industrial urban regeneration processes (Bolognani 2012), children and young people emanating from ethnic minority and/or migrant communities may feel excluded from 'local' discourses and representations of culture which have little in common with their own biographies or migrant identities. Rather, they may inhabit what Bhabha (1994) terms Third Space - where place and culture coalesce in hybrid constellations and are negotiated in a constant dialogue between self and other.

Although deficit approaches associated with class and ethnicity as barriers to cultural participation are increasingly challenged (Jancovich 2017), they prevail in much urban cultural planning where the celebration of local arts and heritage is considered a suitable conduit to engage young citizens in culture, particularly those from 'hard-to-reach' backgrounds. These conflicts are reflected in a somewhat missionary language emphasising 'outreach', 'engagement' and 'participation' of children and young people in culture-led regeneration schemes. Such terminology implies that these stakeholders have to be brought into the realm of mainstream culture, a process that is often sought to be achieved by formal and informal educational interventions by schools, cultural institutions, or youth and community organisations (Pope 2007). Likewise, and despite the recognition of youth cultures as 'creative class' in culture-led urban regeneration (Boland et al. 2017), it suggests that young people are largely considered mere consumers or recipients of culture rather than active producers. This perception is not only reflected in the growing festivalisation of culture for young 'audiences', but echoes more far-reaching diagnoses of childhood and youth as being increasingly subjected to neoliberal consumer cultures and experience economies (Kennelly 2016).

Notwithstanding the often top-down nature of youth participation, evidence shows that engagement with, arts, culture and heritage not only has benefits for children's education, selfesteem and wellbeing, but also forges powerful feelings of place, identity and sense of belonging (Warwick Commission 2015). Indeed, 'place making' has become a central watchword in culture-led urban planning, and is particularly directed towards children and young people, believed to be the current shapers and future beneficiaries of regeneration. Understood as the manifestation of space 'lived' and brought into the realm of the human scale (Tuan 1990; de Certeau 2008), the notion of place lends itself well to capturing the performative, creative and poetic dimensions of urban space. As for marginalised cities in search for transformation, place making has thus become an apt strategy that works both inwardly, for fostering feelings of local pride, identity and sense of belonging, as well as outwardly, in the context of city marketing (Pollock \& Paddison 2014). 
For Hull UKCoC 2017, place making was identified as one of five 'key impact areas' and aimed at improving "perceptions of Hull as a place to live, work, study and visit" (CPPI 2018, 110). Embedded in a wide-ranging cultural engagement programme facilitated through schools, community organisations, cultural institutions, and volunteering schemes, it was anticipated that place making would particularly resonate with children and young people and help to instil confidence and sense of belonging among these age groups. Whilst the long-term impacts of such a strategy have yet to be assessed, a study by Boland et al. (2017) with young people in Derry/Londonderry, the UKCoC 2013 , revealed that the one-year event nurtured feelings of local pride and sense of place among teenagers. However, its temporary nature, combined with doubts about its long-term impact on socio-economic growth, left many with limited prospects and did relatively little to change their future plans of moving away in search for opportunities elsewhere.

While proponents of culture-led regeneration seek to forge sustainable relationships between children and place, critical observers highlight the increasingly limited stake they hold in the creative and cultural appropriation of urban space. Indeed, scholars have diagnosed an ongoing 'disappearance' of childhood spaces in urban environments due to growing anxieties among parents, educators and councils with regards to risks such as 'stranger danger', knife crime, terrorism, traffic or environmental pollution (Horschelmann \& van Blerk 2011). Similarly, Toon (2000) shows how teenagers, particularly those living in disadvantaged urban areas, are subjected to spatial exclusion, social control, and surveillance which seek to 'purify' the public sphere of deviance and disorder often projected upon this age group. Against this backdrop, it is not surprising that 'place making' in culture-led regeneration is predominantly confined to highly controlled and risk-free communal zones such as educational and cultural institutions (schools, public libraries, museums), or specifically themed spaces of leisure, spectacle or edutainment (i.e. festivals).

Children's uses of, and relative exclusion from, urban place and culture also raises more fundamental and ontological questions about children as 'beings' (i.e. social actors in their own right) vs. children as 'becomings' (i.e. adults in the making) (Uprichard 2008). While those who diagnose the exclusion or 'disappearance' of childhood in the era of growing urbanisation seem to advocate the former, proponents of youth participation in culture-led urban transformation and education schemes appear to emphasise the latter. For example, this is reflected in the legacy and sustainability plans of both UK Cities of Culture to date, as Derry/Londonderry 2013 stressed the role of young people as 'cultural assets' or 'ultimate beneficiaries' (Boland et al. 2017), while Hull 2017 prioritised skills development for children and youths, and "to use the power of culture to generate a new population of thinkers and thinking in Hull" (CPPI 2018, p. 44). 


\section{The UK City of Culture Programme and the case of Hull in context}

The UK City of Culture Programme was launched in 2009 as part of New Labour's developing approach to culture-led regeneration, which sought to emulate the overall success of Liverpool as European Capital of Culture in 2008 (Cox \& O'Brian 2012). Under the auspices of the Department for Culture, Media and Sport (DCMS), a working group was formed and recommended that the designation be given to a UK city once every four years. The first city to claim this status was Derry/Londonderry in Northern Ireland (2013), followed by Hull (2017) and Coventry (2021). According to the DCMS (2014, n.p.), the main aims of the City of Culture programme are to "encourage the use of culture and creativity as a catalyst for change", to "promote the development of new partnerships", "encourage ambition, innovation and inspiration in cultural and creative activity', and to "align the cultural excellence of national arts organisations to support the year with cultural highlights that will attract media attention, encourage national tourism and change perceptions." This language suggests that the UKCoC initiative is geared towards urban regeneration and city branding (Cox \& O'Brian 2012), which is reflected in the three UKCoCs selected to date, all of which are severely affected by socio-economic decline, and in the case of Derry/Londonderry, by political conflict and sectarianism (Boland et al. 2016).

For Hull, a city of approximately 260.000 inhabitants, the UKCoC status was seen as a golden opportunity to boost economic growth and to reinstall civic pride and confidence among its citizens (Hull UKCoC Ltd 2016). Situated in East Yorkshire at the confluence of the Humber Estuary and the River Hull, Hull has been an important English port and fishing town since the Middle Ages. The town particularly prospered during the $19^{\text {th }}$ and early $20^{\text {th }}$ centuries (gaining city status in 1897), which lead to a population peak of more than 300,000 in the 1930 s and also saw increased migration to the city from across and beyond Europe (Evans 2017). During the latter half of the $20^{\text {th }}$ century, Hull experienced a period of continuous economic decline, which was accelerated by the collapse of the city's distant-water fishery in the 1970s, as well as the reshaping of the international port industry towards automation and containerisation (Starkey et al. 2017). Together with the disintegration of its industrial and maritime significance, Hull's relative geographical isolation within the UK lead to decline and fostered a negative national image linked to poverty, urban decay and socio-economic deprivation. Figures published by the Office for National Statistics (ONS) revealed that, in 2015, Hull possessed the third-highest unemployment rate in the UK and saw the highest number of job-seeker allowance claims. In the same year, Hull came third in the English Index of Deprivation (DCLG 2015), and despite recent improvements, the city continues to rank high in national statistics on teenage conception rates, educational under-attainment, or the number of young people not in education, employment or training (NEET) (DfE 2016). It is estimated that $27.4 \%$ of Hull's children grow up in poverty and deprivation, which is significantly above the national average (DCCE 2016). 
In terms of ethnic diversity, $89.7 \%$ of Hull's population define themselves as 'white British', which is 10\% above the national average (Hull City Councils 2017). Recent statistics published by Migration Yorkshire (2018) reveal that approximately 9\% of the community in Hull were born outside the UK, with the city's largest minority group being Polish, and seeing a growing population of Rumanian migrants in recent years. Migration Yorkshire also suggest that $16 \%$ of primary and $12 \%$ of secondary pupils (4700 in total) have a first language that is not English, which is slightly below the regional (i.e. Yorkshire and the Humber) average.

In view of Hull's relative economic deprivation and discouraging youth statistics, it is not surprising that children and young people were put at the heart of the strategic priorities for the 2017 UKCoC programme. This included an ambitious and far-reaching education and skills programme, entitled No Limits, which sought to promote active participation and access for all children and young people across the city. The aims of this initiative were to link cultural projects to key areas of the curriculum, to celebrate local history, heritage and culture in schools, as well as to enable children and young people "...to shape their own interpretation of what culture means to them" (Hull 2017 Ltd p. 23). Among other projects, No Limits sought to implement this strategy by artists-in-residence schemes in schools, cultural and artistic commissions for young people, collaborations between schools and cultural institutions, as well as professional development opportunities for teachers. According to preliminary evaluations, Hull 2017 Ltd worked with more than 100 primary and secondary schools, and managed to reach out to more than 56.000 children in the city during 2016 and 2017 (CPPI 2018, p. 44).

\section{Methodology}

This article is based on research undertaken with a sizable group of children, educators and cultural practitioners across Hull during the year it celebrated its UKCoC designation. The main objectives of the research were to establish what children and young people across Hull consider 'culture' to be in the context of this event, how they 'use' and appropriate the cultural offers provided, and how (or if) UKCOC has had an impact on their perceptions of Hull as a place.

In total, we worked with 79 children and young people from four primary schools, four secondary schools, one 'special' school (focused on young people with social and emotional difficulties) and one 'alternative' education setting serving young people who, for various reasons, 'dropped out' of formal education. In collaboration with teachers and the UKCoC Learning and Participation team (who implemented the No Limits programme), it was identified that children in Year 4 (age 8-9) in primary schools and Year 10 (age 14-15) in secondary schools, represent a suitable sample. This is because children of these age groups are at particular developmental and educational transition points which impact on self- and public awareness, independent thinking and spatial practice. All 
schools across the city were invited to participate and from those willing, ten schools were purposefully selected to represent a balanced geographical spread across Hull and to reflect the demographic diversity of the city with regard to socio-economic position and levels of ethnic diversity. Although we considered children's ethnicity or migration backgrounds as potentially influential variables in assessing their interpretations and uses of 'culture', we did not take a detailed account of this. This was largely due to the voluntary, self-selecting nature of pupils' participation which did not allow for a more purposive approach. However, and drawing on the immediate conversations with pupils and information provided by teachers, we estimate that at least $10 \%$ of participants emanated from migrant or ethnic minority groups.

Semi-structured, participatory focus groups were identified as appropriate means to capture what children and young people had to say about culture and place. These were conducted by the researchers in each setting and, for safeguarding reasons, most schools maintained that a teacher had to be present. The focus groups lasted between 45 and 80 minutes each and involved the utilisation of a number of A4-sized visual image cards, designed to facilitate debate and flow of conversation among participants. Whilst the choice of this participatory tool was based on successful previous application (...), the selection of images was informed by existing analyses of culture, place and youth in urban contexts. The cards featured visual representations of 'everyday' urban culture such as work, housing, transport, tourism, education, sports, cultural and heritage institutions, landmarks. After briefing pupils about the focus group format, and a general scoping of their engagements with Hull UKCoC (within and beyond the school), the image cards were shown to the pupils in a sequential order so as to discuss any associations that emerged between the images and their personal understandings of 'culture'. Not all of the prepared image cards were used with all of the children as this depended on the dynamics, length and depth of conversations on particular items.

In addition, we interviewed a total of 17 teachers, as well as eight 'cultural practitioners' who worked independently with schools and local communities to implement cultural participation across Hull through the No Limits programme. The purpose of including these participants was to find out about their experiences with children's uses of, and attitudes to, 'culture' in the celebratory year, and how this affects their sense of place. The recorded focus groups and interviews were transcribed and subjected to rigorous thematic analysis (Kohler-Riessman 2008) which resulted in a number of emergent key themes that were set in relation to the prime research questions guiding this study. 


\section{Children's views on 'culture' in the context of Hull 2017}

Our findings indicate that, among the younger research participants (age 8-9), 'culture' was frequently associated with 'fun', 'playfulness', 'happiness' and 'emotional wellbeing'. Likewise, it was frequently linked to ideas about personal agency, liberty and freedom of expression which is, among others, expressed by personal acts of creation. Here are some of the recurrent statements we captured with regards to children's understanding of 'culture':

"I think culture is about making people happy, so they are not as mithered as they used to be." (boy, PS)

"I think culture is supposed to be fun and you don't have to do it if you don't want to." (boy, PS)

"I think culture is art because it's something that everyone can do and there's no wrong or right way to do it." (girl, PS)

"Culture is about creating stuff and making what you think is right, even if other people don't think it's right." (boy, PS)

For some children 'culture' also reflected more 'hands-on' and practical processes of creation, a view that was frequently voiced by children attending schools in what can be described as 'working class' neighbourhoods. For example, discussing an image card depicting the theme of 'housing', a girl had the following to say:

"I think culture is like, you respect what people have made for you to look at, and they have built it for you to live in, or something...". (girl, PS)

Whilst children stressed the wider democratic, egalitarian and creative dimensions of culture, most of them also made direct references to what culture means in relation to their own city. As the following quotes indicate, the city's built environment, its history and heritage - much promoted in Hull's primary school curricula in 2016 and 2017 - represented significant cultural reference points:

I think it is like, the buildings like, what you are famous for, and what you are proud of in the city (girl, PS)

I think culture is like, it is expressing, what you are asserting, what your city has like been through and the history of it, and you are proud of what it is (girl, PS)

It is interesting to note, that the more recent history of the city, particularly the historical rise and fall of Hull's fishing and port industry, struck a chord with children. As most of the interviewed teachers revealed, Hull's maritime heritage had also been made an integral part of learning about local social history, and the subject of various events for children within the UKCoC programme. While some children referred to personal family histories linked to Hull's fishing heritage, for most of them UKCoC provided the first opportunity to engage with what seemed to them a distant past. Discussing the image card themed around 'work', one girl contemplated the relationship between this part of Hull's history and the wider meaning of 'culture': 
'I saw a picture of work and it was a trawler in Hull. Working on the trawlers kind of made a piece of our history, and history is kind of like culture because you have different things, and different things make history. And if you didn't have the history, you wouldn't really have the culture. (girl, PS)

While many children, particularly those from inner city schools, showed an overall good knowledge about established local cultural institutions (museums, galleries), and have visited these as part of school or family trips in 2017 , they seemed to be particularly aware of artistic interventions in public space. For example, 'The Blade', a 75-meter wind turbine rotor blade designed by artist Nayan Kulkarni for Hull city centre in 2017, or 'The Weeping Window', a large-scale temporary sculpture comprised of thousands of ceramic poppies attached to Hull Maritime Museum, were frequently mentioned as positive examples of the UKCoC programme and something that beautifies the city. However, there were also less assuming additions to urban public space, that enthused the younger children. When asked to give some examples of things and places that would attract visitors to Hull, children were quick to highlight the newly-installed, multi-jet water fountain in Hull's central Queen Victoria Square, which is part of a longer-term inner-city regeneration programme:

I think people would go to Hull because we had a really big history about trawlers and we've got the Maritime Museum and the Ferens Art Gallery. And, like, we've just got lots of things and we've got the Hull Fair, and now that we have City of Culture, people are probably coming. And now that we've got the fountains, I think people are coming more for that, because my friends came and they loved the fountains. (girl, PS)

Whilst narratives like the above could be easily dismissed as 'playful', 'innocent' or 'naïve', they reveal some profound personal engagements with 'culture' and place as something that conjures up ideas of agency, creativity, equality, ownership, respect and a deepened sense of place. Somewhat unexpectedly, this level of abstraction was also noticed by the teachers who attended the focus groups and often expressed how surprised they felt about children's openness and depth of understanding when it came to unpicking what 'culture' and 'place' means to them. Having outlined some of the statements by primary school children, the following sections present narratives by children in secondary schools.

\section{Culture and Place among older children:}

Unlike primary school children's seemingly more universal interpretations of culture as 'creativity', 'freedom' or 'fun', young people in secondary schools (SS), as well as those in the 'special' (SpS) and 'alternative' schools (AS), tended to associate culture more specifically with the notion of place and Hull as 'their' city. Below are some typical responses we recorded among this age group when asking what 'culture' means to them:

"I think culture is what makes a place because if you didn't have any culture it would just be the same as everywhere else." (boy, SS) 
"I don't know, I think culture is where you decide to live and the people you have around." (girl, AS)

"I think culture is what represents your country and your city, the place you live in and [it is] about fun and bringing people together." (boy, SpS)

"Like, culture means the people and the place." (girl, SS)

"I feel like culture is what... represents us. And I really like what, like, we have in Hull, like, we have like Wilberforce and all this amazing culture, like arts and everything...and what makes us mainly, like history as well, so what makes us us." (girl, SS)

"I think culture is what makes you as a person; the food you like, the things you do, the place where you live, what you watch, how things are done with you and your surroundings." (girl, SS)

This selection of quotes indicates young people's emphasis on place and their own social and geographical horizons within the city and in relation to a wider national and international cultural imagination. Similar to the younger children, teenagers referred to local history and heritage as important manifestations of culture and place, and something to be proud of. For example, and representative of other statements, one girl said:

I think it's like...the history and the place, it's like everything that's happened in the past represents slightly what it is now, like before, it's not because of the like huge fishing industry, ..., like it's worldwide now but it started here... (girl, SS)

While references to local history and heritage were frequent, the question whether, and in what ways, established local cultural and heritage institutions (i.e. museums, art galleries, theatres) were utilised by them in 2017 , the young people generally struggled to confirm that this was the case. The following narrative sequence, recorded in an inner-city secondary school, is quite representative of young people's responses:

I think you wouldn't choose to go to it [museum], ... but if you have time to kill (girl, SS)

Male classmate: “...and you might have had your Macdonald's half an hour ago or something”

"I don't think I would like to go in more than once... (girl, SS)

In a similar vein, a girl from the alternative school, reflected on her relationship with 'high' culture:

"The nearest I got to know, like, anything about culture to do with theatre and stuff like that, is that Romeo and Juliet was set in Verona." (girl, AS)

Young people's understanding of culture was recurrently related to their experience of ethnic and cultural diversity (or the lack of it) within the city, as well as in relation to other places and, sometimes, in relation to, or conflict with, older generations:

"... it's different because if you go to central London there's going to be loads of different ethnicities and stuff and people bring their own culture. Whereas, if you come to Hull, it's a lot more WhiteBritish people than there is anyone else, so there's less culture from other people." (girl, SS)

“...like race, religion, ethnicity and things like that. I don't think... like my granddad's really oldfashioned, and by really old-fashioned I mean really racist. And I think it's that generation that maybe don't understand. Like they believe what the media like wants them to believe." (girl, SS)

"...I think it's different cultures all coming together showing that we all probably have more in common than we think, enjoying the same things but different..." (boy, AS) 
Another theme that emerged from the focus groups was the often self-deprecating awareness that Hull is, indeed, a place on the margin, which is easily overlooked by outsiders and has little on offer to make it stand out:

There is nothing really big here..., nothing massive like, that as soon as you think of it you'd think Hull. Like, if you think of Big Ben, you think of London. But, there is nothing like that here (girl, SS)

Hull is a small town in a way, compared to others and you'd normally just fly over it in like a map or whatever... (boy, SpS)

At the same time, teenagers generally felt that the UKCoC designation has enormously contributed to putting Hull 'on the map', and has enhanced the overall image and confidence of the city, and one may add, their own sense of place:

"Like normally people sort of like... they might bypass us when they're going up north and you see it on the motorway, you're like, 'I ain't going to that place', and drive by it. And then like now people are sort of coming and having a look round and, you know, it's nice. (boy, SS)

Female classmate: "Yeah, it is nice to sort of know that people know where we are."

As reflected here, the presence of an increased number of visitors to the city during 2017 , seemed to have had a positive effect on young people's awareness of Hull's special, if temporary, place in the limelight. Similarly, a female participant in a different focus group shared the following telling anecdote about her encounter with tourists in the city centre:

"...in town I heard someone saying about going back to a hotel, and I was thinking, 'Why on earth would you come here on holiday?' And it sort of like clicked that there is stuff going on in the city and, you know, visiting family and that, and have a wander around..." (girl, SS)

Statements like the above reflect awareness, confidence and pride in knowing that Hull's image had improved in relation to the 'outside' world and seem to positively resonate with the UKCoC organisers' overarching vision to 'Tell the world' and to present the story of 'A city coming out of the shadows' (CPPI 2017). Likewise, they parallel findings emerging from Boland et al.'s (2017) study on Derry/Londonderry which clearly showed that the UKCoC status enhanced young people's pride and confidence in the city. While Hull's positive outward-facing image change was frequently mentioned, the majority of teenagers also highlighted inward-facing benefits in relation to civic pride, and similar to Derry/Londonderry 2013, made them feel more connected with the local community. To some extent this is also reflected in young people's frequent use of 'we' and 'us' when referring to Hull. Interestingly, the perception that UKCoC has helped to make the city an overall 'cleaner' place emerged as a recurring theme. The following conversation, captured in a focus group in one particular secondary school, is rather representative of the wider sample:

"I feel like it's cleaner, like it sounds really daft, but do you know when you're walking round somewhere and it's like, I notice it's not as in like muck, but it's just there's a lot of like litter and things like that and it's just... it's not aesthetically pleasing. And now they've added the fountains and they've redone the paths..." (girl 1) 
“...I think people are giving a lot more respect for it as well, like people aren't going round trashing

it, but because it's got a name and because we are the City of Culture, I think we've gained a lot more respect for what we have because people have put effort into it so we need to put the respect in." (girl 2)

In what follows, we further elucidate some of the major themes that surfaced in the conversations with children and young people and which, we believe, can shed light on the role they play in culture-led urban regeneration processes.

\section{Discussion}

The narratives presented in the previous paragraphs allow some remarkable insights into children's and young people's understanding of 'culture' and 'place' in the context of a large-scale, if temporary, culture-led urban regeneration project. The comments shared by primary school children clearly reveal their overall positive associations with 'culture' and 'place' in the context of UKCoC. Our findings show that to them, culture is primarily about fun, happiness, creativity, agency and freedom of expression which is not necessarily place-bound, but indicative of a wider imagination that takes account of social and emotional wellbeing. Indeed, the analysis of statements seem to confirm existing evidence that engagement with 'culture' has clear benefits on their overall wellbeing (Warwick Commission 2015).

It is important to note that such a positive assessment of culture was shared by children from different socio-economic backgrounds across the city. The teachers and outreach professionals also indicated that the benefits of culture on children's wellbeing were clearly recognised in socioeconomically disadvantaged, and often peripheral, working class communities. This runs counter to findings from Derry/Londonderry UKCoC 2013 (Boland et al. 2016), where, despite well-intended promotional campaigns, working-class communities dwelling on the margins of the city generally felt excluded from cultural events that predominantly took place in central locations. It seems that in Hull, besides deliberate attempts to include urban peripheries and council estates in the UKCoC programme, schools played a catalytic role in engendering interest and participation in marginalised working-class communities (CPPI 2017). However, the lack of financial resources available to schools and families in these areas to reach, and pay for, cultural activities beyond their neighbourhoods, was still seen as major barrier. Albeit sporadic, such evidence may help challenge established diagnoses of voluntary disengagement and segregation from culture-led regeneration programmes among those who, due to their working-class background, are deemed to lack sufficient cultural capital compared to higher income and more educated middle classes.

While younger children, particularly in inner-city schools, demonstrated a good knowledge about Hull's established cultural and heritage institutions (i.e. museums, art galleries, theatres) and engaged in a host of creative activities within the No Limits education programme, they seemed to 
particularly appreciate cultural experiences in accessible, low-threshold public spaces. For example, temporary art installations, aesthetically pleasing and 'socially responsible' murals and graffiti were often mentioned as adding something 'new' or 'different' to the city and their everyday lives. Children also highlighted more mundane, albeit perhaps more playable additions to public space, such as the newly installed jet fountain which has become a popular family attraction in the city centre. These examples show that sensible public art interventions, as promoted by Hull UKCoC, have a real impact on children, particularly if they can be used and serve an integrative agenda that promotes play, creativity and intergenerational encounters (Soreanu \& Hurducaș 2016).

Another observation we would like to emphasise is that schools play a pivotal role in sensitising children towards culture and place. Representing sites of learning, creativity and socialisation, as well as being contact zones for communal life, a large number of primary schools in Hull actively utilised the UKCOC designation to broker 'culture' and 'place' to younger children, their parents and the wider community. As several interviewed teachers revealed, the event also presented them with a rare opportunity to break, at least temporarily, with restrictive national curricula, and to promote creativity, playfulness, mobility, and more integrated learning about (and with) local history, heritage and art.

The active engagement of primary schools in the No Limits educational programme has been hailed a 'success story' for “...raising aspirations, abilities and knowledge through participation and learning..." among young residents (CPPI 2018:168). More profoundly perhaps, initiatives like these demonstrate that abstract structures of feeling associated with 'place' and 'culture' are no standalone items, but afforded by learning and early pedagogical interventions that can have a lasting effect on children. Whilst there is a wealth of educational scholarship on the benefits (as well as possible ideological contestations) of 'place-based' or 'place-conscious' pedagogies (Nespor 2008; Comber 2011; Tsevreni 2014), theorists and practitioners in urban planning and culture-led regeneration are still reluctant to engage in such debates. To further mutual theoretical dialogue and cross-fertilisations between these fields would thus be highly desirable (Morgan 2012). Whilst more generic notions of freedom, happiness, play and creativity represent dominant themes among primary school children, associations with 'culture' and 'place' among young people in secondary schools show a somewhat different picture. Our findings indicate, that Hull's UKCoC status had an overall positive impact on teenagers, and seemed to enhance their sense of place, as well as feelings of respect, pride and ownership towards the city. Much of this resonates with Boland et al.'s (2017) research with secondary-level pupils in Derry/Londonderry (UK CoC 2013), which showed that the event made young people feel prouder of being from the city. Also similar to the Derry/Londonderry study, the young people of Hull clearly recognised the economic benefits of the 
UKCoC event (e.g. when discussing work, employment or tourism), but this was generally seen as a side effect of the event rather than its main purpose.

Unlike their younger counterparts, the Hull teenagers tended to stress the relational qualities of place and culture afforded by UKCoC, for example the ways in which the event has raised national awareness of the city and has, at least temporarily, put it on a larger map. For some, the mere presence of tourists in the city in 2017 seemed to have an 'eye-opening' effect, and to evoke a sense of civic pride in sharing their city with others. Young people's relational interpretations of culture and place also quite often touch upon wider socio-political discourses in the UK such as geographical and economic marginalisation, the presence (or absence) of cultural diversity, or the prevalence of uneven power relations between centre and periphery (i.e. the cultural and economic hegemony of London, or the English 'North-South Divide'; Berry \& Giovannini 2017). Such critical reflections on culture and place demonstrate a high level of reflexivity among young people from different socioeconomic backgrounds when it comes to defining their relation to culture, place and self.

While 'traditional' cultural events or institutions such as museums, galleries, theatres might not rank high on young people's agendas and seems to confirm existing research (Striepe 2015), teenagers show a great deal of sensibility and respect towards local history and heritage as meaningful representations of culture and place. These items are not only seen as key identity markers for the city towards 'outward' recognition, but are equally valued as significant personal and communal reference points that, as one teenage girl aptly put it, define what "...makes us us". Similar to younger children, albeit being arguably more mobile and independent in their use of urban space, the teenagers emphasised how UKCoC has altered their perception of public and communal space, predominantly, but not exclusively, in the city centre. For example, the large-scale public art installations mentioned earlier, were frequently referred to as places to meet or 'hang out', as well as attractive sites to be photographed and shared on social media. In particular, the sense that Hull had become an overall 'cleaner' place was strongly noticed by adolescences and seen as a positive development that not only signalled, but commanded respect and commitment towards communal urban space. Such sense of order and cleanliness lies in stark contrast with public policy interventions that see young people having a potentially polluting and disruptive influence on urban environments (Toon 2000).

When it comes to assessing the role of schools in facilitating cultural engagement, learning and place-making, our findings reveal that, compared to primary schools, secondary schools mostly felt left out of the wider UKCoC education and participation programme. According to many interviewed teachers and cultural practitioners, the lack of time and resources, half-hearted support from the central UKCoC management, as well as perceived pressures to meet curriculum targets, seem to 
have hampered opportunities to fully engage in the event. In fact, cultural activities and curriculum interventions in secondary schools heavily depended on the goodwill and enthusiasm of individual teachers, who dedicated much effort and extra hours to work with the young people on specific projects alongside the main UKCoC programme.

The relative exclusion of secondary-school children from the official UKCOC educational programme is perhaps symptomatic of a wider discourse that sees this age group as 'problematic' or 'hard to reach' when it comes to assess their 'engagement' in culture-led urban regeneration and urban planning more generally (Harris et al. 2010). The preliminary evaluation report of Hull UKCoC revealed that the No Limits programme "...provided extensive engagement with young people" and "...has been generally successful in growing support for creative learning in Hull". However, it also indicated that many of the educational flagship initiatives were either targeted at very young children or the 16-24 age group, and that support for creative learning for all children presents a "continuing challenge" which needs to be championed in the future (CPPI, 2017, 168).

Building on the above findings, our study highlights the need to recognise schools as pivotal sites for young people where they are not only enabled to 'use' the culture their city has to offer, but see themselves playing a vital part in the city's cultural production. To this end, we encountered various examples of good practice during our fieldwork such as theatre or music performances staged for neighbouring publics, creative projects with international partner schools, as well as music, art and photographic competitions on school premises. Whilst most of these initiatives fell under the remit of extra-curricular activities, teachers reported on the positive impact they had on pupils' social and educational wellbeing, sense of place and community, learning and personal achievement. Evidence like this highlights the significance, yet continuing undervaluation of art, creativity and culture in UK secondary schooling in favour of STEM subjects, a hotly-debated socio-political issue at present (Allina 2018), and one that goes beyond the scope of this article.

\section{Conclusion}

In this article, we set out to explore what children and young people perceive 'culture' to be within the culture-led urban regeneration project of Hull UKCoC 2017, and how these perceptions impact on their sense of place and belonging. Going beyond dominant utilitarian conceptions of culture as an 'economic driving force' in regenerative urban planning, and trying to challenge some existing myth around youth 'dis/engagement', our findings reveal a complex array of ways in which children and young people interpret and utilise 'culture' and 'place'. Our findings suggest that, in line with the objectives with regards to 'place making' set out by the UKCoC programme, the event has indeed succeeded in increasing confidence and sense of place among younger people. As for primary school children, this may not be that obvious since 'culture' is predominantly associated with more 
private expressions of creation, happiness and wellbeing that are not necessarily place-dependent. However, children's increased sensitisation towards 'their' city through planned curriculum interventions and 'local' learning activities has certainly enriched their perception of culture and Hull as a place they can relate to. Developmental psychologists and childhood geographers may be quick to highlight the biological and social underpinnings of 'spatial cognition' during childhood which are afforded by education and socialisation, and determine sense of place (Proulx et al. 2016). While we cannot contest such disciplinary truths, the ways in which culture-led regeneration contributes to the enculturation of children towards a particular place through educational means, may have a profound impact on them and deserves further scholarly attention. Here, we have indicated that additional cross-fertilisation between urban cultural planning and an existing wealth of expertise in the field of place-based education can provide a worthwhile avenue to further explore the formation of children's understanding of culture, place and sense of belonging.

Similar to the younger children, the teenagers participating in this study, shared overwhelmingly positive associations with 'culture' and 'place' in the context of Hull UKCoC 2017. Indeed, our findings suggest that UKCoC has augmented their confidence and pride in Hull and enabled them to locate both themselves and their city more firmly in a wider social and geographical imagination. Among adolescences, both culture and place are deeply intertwined concepts which help them to ground their identities in relation to self and other (e.g. in ethnic or generational terms), the city and the country, or their place within local communities. While increased feelings of pride and respect for 'their' city dominated young people's narratives and replicate findings from Derry/Londonderry 2013 (Boland et al. 2017), they also recognised legacy-driven approaches to culture as an economic resource for urban regeneration and transformation (Evans 2005). Yet, at no point in the focus group discussions, either implicitly or explicitly, would young people refer to themselves as active 'shapers' or 'catalysts' of urban cultural change, nor consider their own (youth) cultures a valuable 'resource' or 'asset' in culture-led regeneration - a language widely used in service-led urban planning, event programming and cultural policy making (Day et al. 2011). Such a language not only seems to reveal existing adult projections on children and young people as mere 'consumers' or 'beneficiaries' of culture-led regeneration, but also affirms dominant assumptions of children as 'becomings' who will reap the benefits of culture-led 'place making', rather than being seen as active agents who inhabit and co-construct place and community within diverse urban settings.

Our findings suggest that, contrary to prevailing assumptions, young people are neither overly 'apathetic' nor 'activist' in their 'engagement' in culture-led urban regeneration. Rather, and in line with Harris et al.'s assessment (2010), they tend to find more 'ordinary' and 'informal' ways of relating to place and culture within their urban imagination. If there are lessons to be learned from 
this study for urban cultural planners and policy makers, it would be to engage more critically with these 'ordinary' and 'informal' ways of cultural interpretation and place making among young people, without reducing informality to the realm of popular culture, edutainment or the luring power of spectacle. This would mean to acknowledge young people not merely as 'users' or 'consumers' of specifically tailored cultural offers, but to see them as active agents in the production of urban place and culture. As this article has shown, schools represent significant nodal points in this process where both 'top-down' and 'bottom-up' approaches of cultural 'participation' and 'place making' can be negotiated in meaningful and perhaps more inclusive ways.

\section{References:}

Arts Council England (ACE) (2014) The value of arts and culture to people and society: an evidence review. Manchester: ACE

Allina, B. (2018) The development of STEAM educational policy to promote student creativity and social empowerment. Arts Education Policy Review 119(2), 77-87

Bennett, T., Savage, M., Silva, E., Warde, A., Gayo-Cal, M. \& Wright, D. (2009) Culture, Class, Distinction. Abingdon: Routledge

Berry, C. and Giovannini, A. (2017), Eds., Developing England's North. The political economy of the Northern Powerhouse. Basingstoke: Palgrave

Bhabha, H. (1994) The Location of Culture. London: Routledge.

Boland, P., Murtagh, B. \& Shirlow, P. (2016) Fashioning a City of Culture: 'life and place changing' or '12 month party'? International Journal of Cultural Policy, DOI: 10.1080/10286632.2016.1231181

Boland, P., Mullan, L. and Murtagh, B. (2017) Young people in a city of culture: 'ultimate beneficiaries' or 'economic migrants'? Journal of Youth Studies 21(2): 178- 202

Bolognani, M. (2012) Good culture, bad culture....no culture! The implications of culture in urban regeneration in Bradford, UK. Critical Social Policy 32(4): 618-635

Butcher, M. and Dickens, L. (2016) Spatial dislocation and affective displacement: youth perspectives on gentrification in London. International Journal of Urban and Regional Research 40(4), 800-816

Christensen, P., Hadfield-Hill, S., Horton, J. and Kraftl, P. (2017) Children Living in Sustainable Built Environments: New Urbanisms, New Citizens. London: Routledge.

Comber, B. (2011) Making Space for Place-Making Pedagogies: stretching normative mandated literacy curriculum. Contemporary Issues in Early Childhood 12(4), 343-348

Colbert, R. (2011) Children's museums as cultural development strategies for urban revitalization. International Journal of Cultural Policy 17(5), 605-625

Cox, T. and O'Brien, D. (2012) The "scouse wedding" and other myths: reflections on the evolution of a "Liverpool model" for culture-led urban regeneration, Cultural Trends 21(2), 93-101

Culture, Place and Policy Institute (CPPI) Cultural Transformations: The impacts of Hull UK City of Culture 2017. Preliminary Outcomes Evaluation, March 2018. University of Hull. 
Day, L., Sutton, L. and Jenkins, S. (2011) Children and young people's participation in planning and regeneration: a final report on the Ecorys Research Programme 2010-11: Ecorys.

de Certeau, M. (2008). The practice of everyday life. Berkeley, Calif, Univ. of California Press. Department for Culture, Media \& Sport (DCMS) (2009). UK City of Culture working group report June 2009. London: DCMS.

Department for Communities and Local Government (DCLG) (2015) The English Indices of Deprivation 2015. Statistical release, 30. September 2015. Available at:

https://assets.publishing.service.gov.uk/government/uploads/system/uploads/attachment_data/file/465791/English_Indic es_of_Deprivation_2015_-_Statistical_Release.pdf. Accessed November 2018.

Department for Education (DfE) (2016) NEET data by local authority. Available at:

https://www.gov.uk/government/publications/neet-data-by-local-authority-2012-16-to-18-year-olds-not-in-educationemployment-or-training. Accessed November 2018.

Department for Environment and Climate Change (DECC) (2016) Child Poverty. Available via Hull City Council at: http://109.228.11.121/IAS_Live/profiles/profile?profileld=7. Accessed March 2019.

Dillabough, J. A. and Kennelly, J. (2010). Lost youth in the global city: class, culture and the urban imaginary. London: Routledge

Elshater, A. (2018) What can the urban designer do for children? Normative principles of childfriendly communities for responsive third places. Journal of Urban Design 23(3), 432-455

Evans, G. (2005) Measure for measure: evaluating the evidence of culture's contribution to regeneration. Urban Studies (5/6), 959-983.

Evans, N.J. (2017) The making of a mosaic: migration and the port-city of Kingston upon Hull. In Starkey, D.J. et al., Eds. (2017) Hull. Culture, History, Place. Liverpool: University Press, 145-178.

Harris, A., Wyn, J. and Younes, S. (2010) Beyond apathetic or activist youth. 'Ordinary' young people and contemporary forms of participation. YOUNG 18(1), 9-32

Horschelmann, K. and van Blerk, L. (2011) Children, youth and the city. London: Routledge.

Hull City Council (2017) Ethnicity. Hull Joint Strategic Needs Assessment. August 2017. Available at: www.hullpublichealth.org/jsna2017.html

Hull UK City of Culture 2017 Ltd (2015) Hull UK City of Culture 2017. Strategic Business Plan 20152018. Available at: https://cmis.hullcc.gov.uk/cmis/Portals/O/HULL2017_STRATEGICBUSINESSPLAN_1518.pdf [Accessed Nov. 2016]

Jancovich, L. (2017) The participation myth. International Journal of Cultural Policy 23(1), 107-121

Jancovich, L. \& Hansen, L.E. (2018) Rethinking participation in the Aarhus as European Capital of Culture 2017 project. Cultural Trends 27(3), 173-186

Kennelly, J. (2016). Citizen youth: culture, activism, and agency in a neoliberal era. Basingstoke: Palgrave

Kohler-Riessman, C. (2008) Narrative Methods for the Human Sciences. Los Angeles, CA.: SAGE

Migration Yorkshire (2018) Hull. Local Migration Profile. June 2018. Summary Document. Available at: https://www.migrationyorkshire.org.uk/userfiles/attachments/pages/664/hullImp-summary-jun2018.pdf

Morgan, J. (2012) The production of urban educational space. International Journal of Inclusive Education 16(5-6), 567-579

Nespor, J. (2008) Education and Place: A Review Essay. Educational Theory 58(4), 475- 489 
Office for National Statistics (2015) Regional Labour Market: May 2015. Available at:

https://www.ons.gov.uk/employmentandlabourmarket/peopleinwork/employmentandemployeetypes/bulletins/regionall abourmarket/2015-05-13. Accessed November 2018.

Pollock, V. L. and Paddison, R. (2014) On place-making, participation and public art: the Gorbals, Glasgow. Journal of Urbanism 7(1), 85-105

Pope, P. (2007) 'I thought I wasn't creative, but...'. Explorations of cultural capital with Liverpool young people. Journal of Social Work Practice 21(3), 391-400

Proulx, M., Todorov, O., Taylor Aiken, A. and de Souse, A. (2016) Where am I? Who am I? The relation between spatial cognition, social cognition and individual difference in the built environment. Frontiers in Psychology 7 (2016), 0-64

Soreanu, R. \& Hurducaș, I. (2016) Children's imaginaries in the city: on things and materials. Children's Geographies 14(4), 422-436

Starkey, D., Atkinson, D., McDonagh, B., McKeon, S., Salter, E. (2017) Hull. Culture, History, Place. Liverpool: University of Liverpool Press

Striepe, S. E. (2015) How some art museums can appeal to teenagers. Journal of Museum Education 38(2), 207-217

Taylor, A. (2011) Reconceptualizing the 'nature' of childhood. Childhood 18(4), 420-433.

Toon, I. (2000) Finding a place in the street: CCTV surveillance and young people's use of public space, in D. Bell and A. Haddour, Eds., City Visions. Harlow: Longman, 141-65

Tsevreni, I. (2014) The Empowering role of arts in a critical pedagogy of place. Children, Youth and Environments 24 (1), 138-157.

Tuan, Y.-F. (1990). Topophilia: a study of environmental perception, attitudes, and values. New York, Columbia University Press.

Uprichard, E. (2008) Children as 'Being and Becomings': children, childhood and temporality.

Children \& Society, 22, 303-313.

Warwick Commission (2015) Enriching Britain: Culture, Creativity and Growth. Coventry: University of Warwick.

Woodman, B. and Bennett, A. (eds) (2015) Youth Cultures, Transitions, and Generations: Bridging the Gap in Youth Research. London: Palgrave Macmillan. 